\title{
Sensory deprivation and sensory input in rearing experiments
}

\author{
J. H. S. BlaXTER \\ Zoology Department, University of Aberdeen; Aberdeen, Scotland
}

KURZFASSUNG: Entzug sensorischer Einflüsse und sensorische Aufnahme bei Zuchtversuchen. Marine Organismen, besonders Fischlarven, die in entsprechenden Kulturgefäßen gezüchtet werden, sind vor sensorischen Einflüssen nahezu abgeschirmt. Diese sind jedoch für eine entsprechende Entwicklung der Sinnesorgane und der ihnen zugeordneten Koordinations- und Assoziationszentren wichtig. Gezüchtete Meerestiere sind zudem oft einem ungünstigen Einfluß durch Übervölkerung ausgesetzt. Als Ergebnis derartiger sozialer Stressituationen können u. a. abnorme Verhaltensweisen, morphologische Veränderungen und Wachstumsdepressionen durch intraspezifische Konkurrenz auftreten. Insbesondere für die Aufzucht empfindlicher Meeresfische erscheint es angebracht, in den Zuchtbehältern eine natürliche Umwelt zu schaffen.

\section{INTRODUCTION}

It is the intention of this contribution to speculate on the nature of the rearing tank as an environment for young marine organisms. The main group concerned is the teleost fish, though much of what is said may be true for invertebrates. A school of thought exists which considers that the rearing tank should be uterine in nature, cosseting the young stages of animals and buffering them from any form of biotic shock due to predators or larger organisms, and protecting them from abiotic shock caused by violent changes or undesirable levels of light, temperature, salinity, oxygen or other physico-chemical factors.

What is not clear is the extent to which sensory input of all kinds is reduced below a "desirable" minimum; "desirable" in that a threshold of input may be required, both for the proper development and functioning of the sense organs and their central connections and analytical mechanisms, and also for the development of learned responses of a physiological or behavioural nature which can only occur if the organism is subjected to stimuli. It is further not clear the degree to which young organisms are subjected to high levels of stimulation of an undesirable nature (particularly at the intra-specific level) since rearing experiments are almost invariably conducted at high density. There are thus two facets to the problem - are the organisms being deprived of desirable sensory input or over-subjected to undesirable input?

In Man the effects of lack of sensory input are well-known (Heron 1957). Sensory deprivation or "brainwashing" leads to extreme susceptibility to input (e. g. pro- 
paganda) which might normally be rejected; hallucinatious or internally manufactured sensory data may also be generated. The sense organs and nervous system are then starved of data to process and a substitute is provided, with a lower threshold of acceptance.

During development the lack of input could prevent the proper morphogenesis of the sense organs and their central connections. The human infant must, in fact, le a $\mathbf{r}$ to interpret images during an increase in the complexity of the sense organs and central nervous system. Later in life, subjects with congenital cataract or corneal opacity experience considerable difficulty when normal vision is provided by an appropriate operation (TREVOR RoPer, personal communication). Considerable flexibility must be involved in vision because the nervous system can suppress the double images produced by diplopia or can compensate for the images produced experimentally by distorting spectacles (WXBURN et al. 1964). Indeed the ability to compensate for the inverted image on the retina is an example of this.

Similar considerations apply in animals (see RresEN 1964). For instance, a number of mammals show strong motivation to obtain adequate sensory input; rats held in stimulus-rich environments have a greater cortex weight than controls. Even minimal changes of stimulation act as powerful and persistant reinforcements in learning of rats deprived of sensory input (SACKETT 1965). Cruder types of deprivation experiments are often conflicting. CHow (1955), for example, was unable to demonstrate any changes in the retina, superior colliculus or lateral geniculate body of monkeys held in the dark or in coloured light; nor was visual function impaired. However, in studies on developing mammals raised in the dark some effects were found in the brain. Globus \& SCHETBEL (1967) found structural changes in the visual cortex of newly born rabbits reared in the dark, while GrLLENSTEN et al. (1967) reported changes in the size of nuclei and internuclear material in the visual cortex, lateral geniculate body and superior colliculi of mice reared post-natally in the dark or with the eyes extirpated. The latter method gave the more extreme changes. In particular, occlusion of the kitten's eye leads to a decrease in the thickness of the inner plexiform layer and loss of ganglion cells (Rresen 1964). Presumably the developing organism is more sensitive than the adult, a factor which, if applicable to lower animals, may be of profound importance in the rearing tank.

The reverse of these considerations is stress (SELYE 1957, BARNETT 1964) which may be defined as any agent which tends to disturb homeostasis. To some extent the term is a "waste-basket" for a great range of stimuli, ranging from physiological or post-operative shock and burns, to fear, crowding, competition etc. The effect they have in common is an increase in adrenocorticotrophic hormone in the blood, with resulting increase in cortico steroids which control carbohydrate metabolism and water balance. There may also be increases in activity of the thyroid and adrenal medulla and involution of the thymus and lymph nodes. Under excessive stress animals may fail to feed (though food is available) but stress can also be lethal without any element of starvation.

The behavioural aspects of stress, apart from predator avoidance, centre round population density and territory holding. Stress may be involved both in the defending of territory and in the invasion of territory already held. Often the aggression 
manifested at these times is ritualised and withdrawal or submission plays an important role. Perhaps the most interesting aspect of intra-specifically induced stress is that stressed animals may unaccountably die, although no physical damage is incurred by the tissues. Apart from loss of appetite there is often no satisfactory explanation of the cause of death. In some cases there may be excessive parasympathetic activity or "vagal" death, the heart beat becoming seriously depressed. According to BARNETT (1964) the concept of excessive arousal must be considered. Arousal seems to be a characteristic controlled largely by the reticular substance in the brain stem and thalamus. Arousal is an important factor - an animal must be adequately aroused for learning processes to occur, but excessive arousal may catse stress beyond the tolerance limit of the animal and a general deterioration both of the nervous system and homeostatic mechanisms results.

\section{INADEQUATE INPUT IN FISH}

As far as the abiotic environment is concerned, experimental work on decreasing input has mainly concerned the long term removal of light. Pfidgreider (1952) found that unilateral blinding of newly born individuals of the genera Xiphophorus and Lebistes caused a reduction in development of the contralateral opric tectum. By the adult stage the ratio of the volumes of the optic tectum on the operated to the unoperated side was $5: 9$, mainly due to a decrease in volume of the ganglion cells (especially the nuclei), rather than a decrease in their number. With early bilateral extirpation of the eyes of Lebistes reticulatus the ganglion cell volumes never increased beyond the just post-embryonic size. Experiments in darkness confirmed that the effect was due to lack of visual input and not to degeneration products from the dying axons of the optic tract.

Intact fish kept in the dark showed no signs of retinal degeneration, the structure and size of the eye and density of retinal elements remaining similar to controls. The fish did, however, become colourless and showed retarded growth (though they must have been able to feed in the dark). Unilateral blinding in species of Hyphessobrycon and Lebistes caused ipsilateral degeneration of the pseudobranch, by a reduction in the frequency of larger actively-secreting cells. With bilateral blinding or in darkness there was a bilateral degeneration of the pseudobranch.

In contrast to these results OGNEFF (1911) found that the retina of goldfish Carassius auratus kept in the dark for 3 years showed marked atrophy. RasQuin $8 x$ Rosenbloom (1954) kept the characin Astyanax mexicanus in the dark for long periods and also removed the lens or entire eyeballs. In the dark with eyes intact there was infiltration of the choroid gland by fat and melanophores; after 50 weeks there was some involution of the retina. If the lens was removed there was degeneration of the retina after 7 months (perhaps due to contact with the environment) in either light or dark. With complete enucleation (eyeball removal) the pseudobranch regressed in both dark and light. Dark-raised fish with intact eyes showed changes in body proportions, accumulation of fat, degeneration of the kidney, atrophy of the thyroid and changes of acidophil and basiphil cell ratios in the pituitary. These con- 
ditions were reversible if the fish were returned to light within 4 months. After one year 16 out of 19 fish died when returned to the light.

Lack of input at a more subtle social level seemed to be a factor in the experiments of BREDER \& HALPERN (1946) and SHAw (1960, 1961), who had difficulty in rearing isolated individuals of the genera Brachydanio and Menidia respectively. Not only was survival poor in Menidia but schooling behaviour was retarded when isolates (reared in bowls with non-reflecting walls) were brought together. The extent to which imitative behaviour in feeding is involved in survival is not clear. Certainly WeLTY (1934) was able to show that learning in adult goldfish was much enhanced in groups. Lack of learning possibilities may also be responsible for the poor survival of and high rate of predation on plaice larvae Pleuronectes platessa reared in tanks and planted out into the wild (Bowers 1966a). This poor survival may have been due to: (a) lack of predators in the rearing tanks; (b) lack of sand for learning the covering and hiding reaction natural to flatfish; (c) inappropriate conditions of light and depth in the tank which prevented the development of a rapid bottom-seeking response in larvae liberated in mid-water; (d) inadequate locomotory powers to escape predators. This has been shown in salmonid hatcheries where inadequate exercise led to poorer stamina (VINCENT 1960) and unsuitable food (Miller \& Miller 1962) was followed by higher mortality and high lactate levels.

\section{INTENTIONAL INCREASE OF INPUT IN FISH}

QASIM (1959) tested the effect of a continuous light or a 7-8 h day : night regime on the survival of larvae of the blenny Blennius pholis and butterfish Centronotus gunnellus fed on Artemia salina nauplii (Fig. 1). There was a steady mortality in both

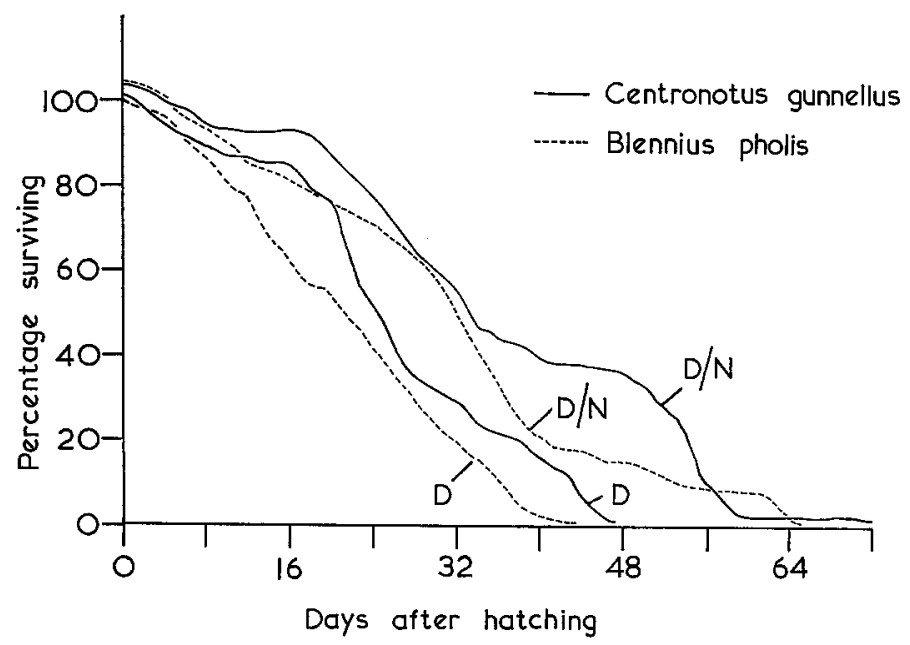

Fig. 1: Survival of blenny larvae under continuous day (D) and a day/night regime (D/N). (After QASIM 1959; redrawn) 
species but the mortality rate was lower under alternating conditions of light and dark, although the feeding period was shorter (the larvae being visual feeders). It seemed that a period of darkness or inactivity may have led to improved survival.

Young medaka Oryzias latipes were reared by Lindsex \& ALI (1965) at sustained temperatures from $20^{\circ}$ to $34^{\circ} \mathrm{C}$ and at temperatures alternating between $22^{\circ}$ and $30^{\circ} \mathrm{C}$ every $12 \mathrm{~h}$ (considered to approximate to natural conditions). There was a $97 \%$ survival in this batch and fewer skeletal malformations compared with the control group held at $22^{\circ} \mathrm{C}$, where survival was only $76 \%$.

MARR $(1965,1967)$ found some evidence of better survival and growth in young salmon Salmo salar which were kept on a grooved substrate in the dark with a fairly rapid turnover of ambient water; compared with the use of a smooth substrate in light with a slow turnover of water. While this improvement in growth was almost certainly due to a reduction in wasteful and needless activity, it is possible that the change of input had an effect on survival.

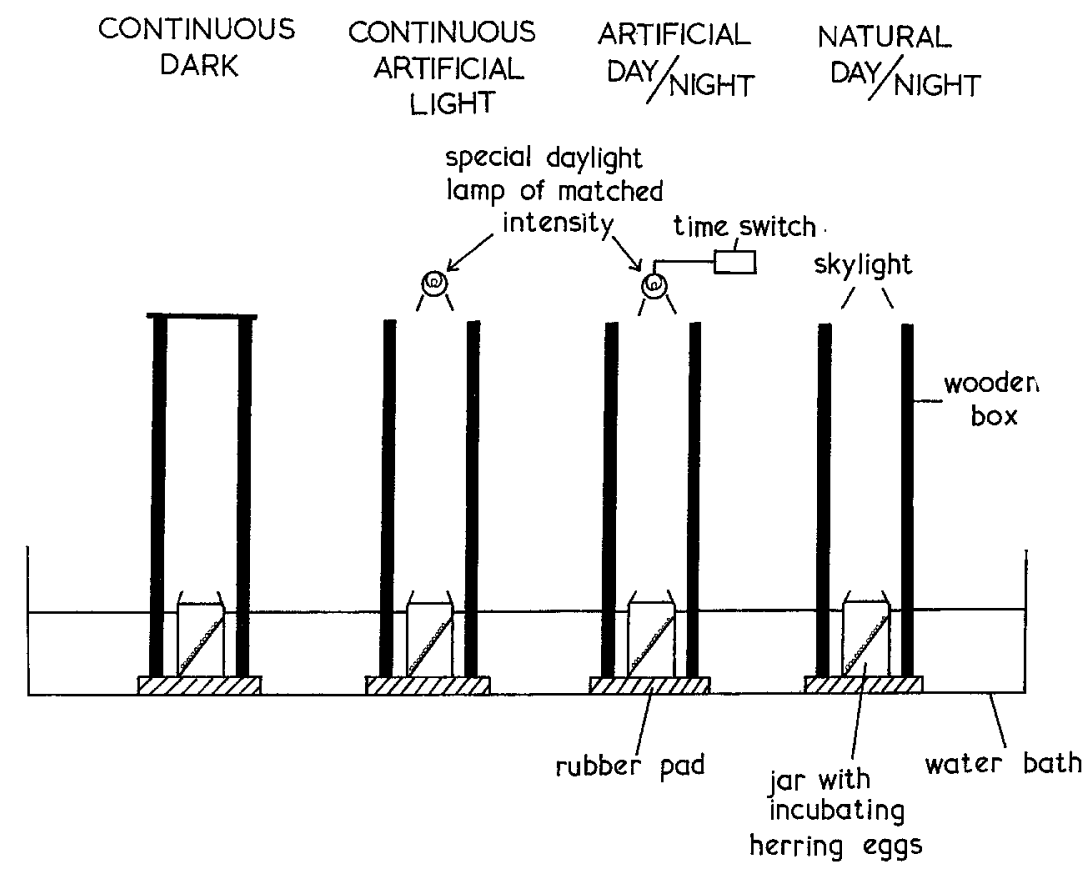

Fig. 2: Diagram of an experiment to test different light conditions on hatching and survival of larvae of the herring Clupea barengus

Unpublished results of preliminary experiments by the present author may be mentioned here.

In the following, the effects of various types of illumination on the hatching success, survival and behaviour of fish larvae and on the development of the eye will be considered. 
Clupea barengus eggs were incubated, hatched and kept to the end of the yolksac stage in four conditions of illumination (Fig. 2). The first batch was held in continuous darkness, the second in continuous artificial light, the third in an $11 \mathrm{~h}: 13 \mathrm{~h}$ light: dark cycle of artificial light and darkness and the fourth in a normal diel cycle of natural light (approximately an $11 \mathrm{~h}$ day and $13 \mathrm{~h}$ night) from an overhead skylight. The artificial light was provided by two $60 \mathrm{~W}$ lamps which matched natural daylight in colour temperature and were set at a distance above the eggs to give the same intensity as natural light near midday from the skylight (moderate cloud). The light intensity averaged about $16 \mathrm{mc}$ (metre candles) at the eggs in batches 2, 3 and 4, but was reduced to about $5 \mathrm{mc}$ later when it was found that the temperature in batches 2 and 3 tended to rise about $1 \mathrm{C}$ degree above the temperature in the other jars.

The eggs were fertilized in the laboratory from gametes brought from the Clyde in February and were reared thereafter in $1 \frac{1 / 2}{1} 1$ jars under the conditions of light given above. The jars were kept in a water bath at $7.5^{\circ}$ to $8.5^{\circ} \mathrm{C}$. The water within the jars was changed (at night) every 3 days and an antibiotic mixture (BrAXTER 1968) was used. Towards the end of the predicted incubation period it was necessary to look at the dark-reared eggs under a dim light for a very brief period each evening to ascertain whether hatching had occurred, and with what success, and eventually to sample the larvae.

The date of main hatching and percentage hatching of the larvae were recorded (Table 1) and samples taken at intervals. In particular, the eyes of two larvae from each batch were examined histologically at hatching and at yolk resorption. In a further experiment three larvae were examined at hatching from Batch 1 and Batch 3 . The extent of retinal masking by pigment was assessed by using a pigment index (Blaxter \& Jones 1967). This is a measure of the extent to which the pigment extends inwards from the periphery of the eye and masks the visual receptors. The ratios between the cones, the cone nuclei, the two main types of nuclei in the bipolar layer and the ganglion cells were also counted and the width of the inner plexiform layer measured relative to the width of the whole retina. The results, given in Table 1 , represent the retinal pigment index and width of the inner plexiform layer averaged over 20 measurements for each larvae. The ratios are based on four counts for each larva. The results of feeding experiments and mortality during feeding are also given in Table 1. With each batch about 60 larvae were dark-adapted for $3 \mathrm{~h}$ (except Batch 1 already in the dark) and then held in light in 51 black-walled plastic tanks with food (Artemia salina nauplii) for $1 \mathrm{~h}$ at first and then overnight. The number feeding at the end of the two experiments could be observed easily as the larvae are transparent. This and the mortality were recorded.

There was no sign of the type of retinal degeneration reported by other authors in any of these experiments, nor were there any other significant differences between the batches except Batch 1 (continuous dark) which hatched earlier (though if anything, the aggregate temperature was lower) showed a higher percentage hatch, but exhibited very abnormal behaviour in the light (the larvae remaining inactively near the surface of the tanks) and gave a high mortality in subsequent short and longer term feeding experiments. None of the feeding experiments was very successful in 


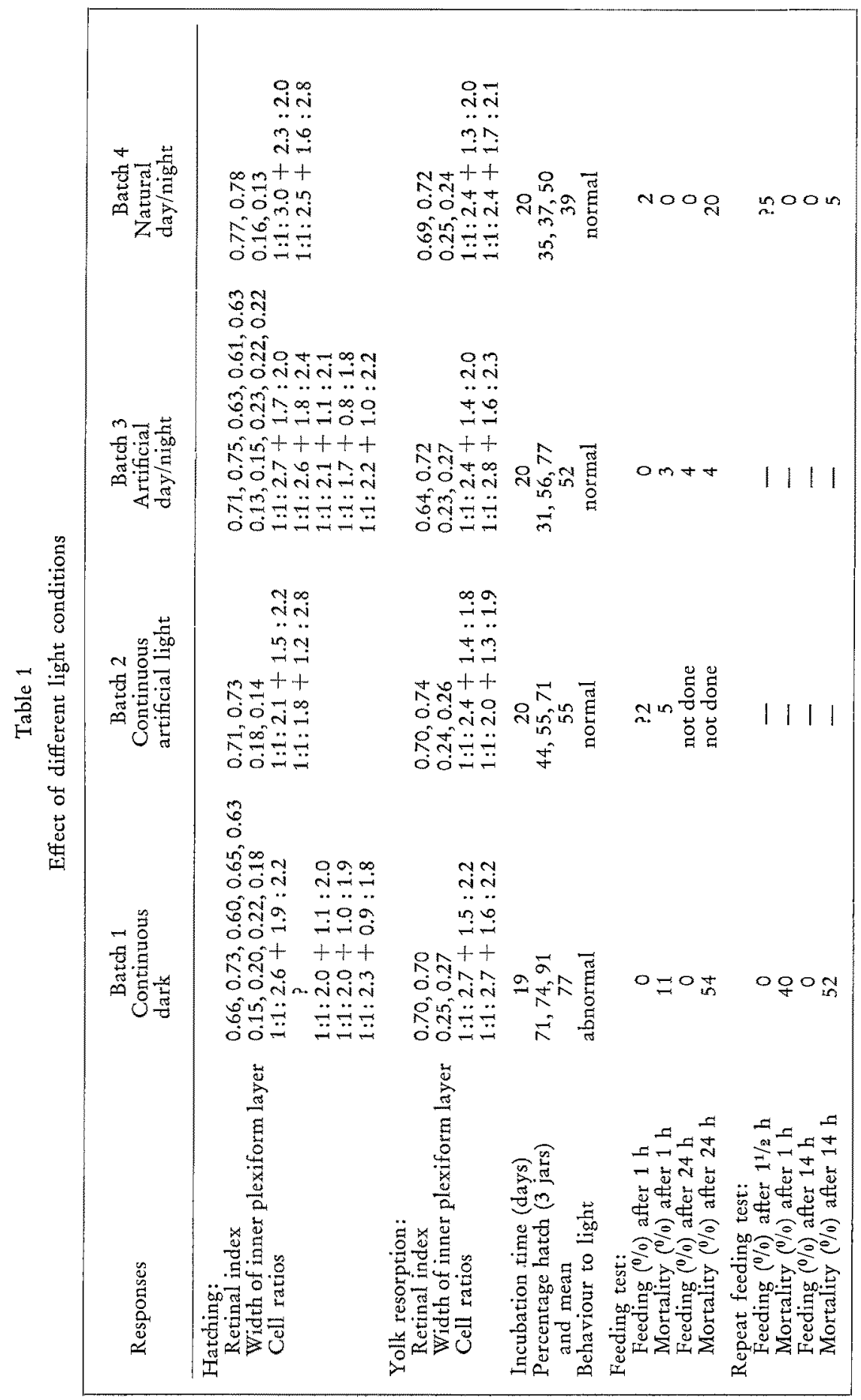


that most larvae failed to feed, but percentage success in feeding is generally low in herring larvae at first feeding (Blaxter \& Staines 1970).

In a second series of experiments larvae of the herring Clupea barengus were kept in two black plastic 2001 tanks. Over one tank (Fig. 3) a changing pattern of shadow was produced by interposing an endless rotating band of gauze between the surface of the tank and the light source by means of two rollers, the gauze having light and dark patches on it. This tank also had a jet of air directed at one corner which caused ripples at the surface. The second tank had stationary gauze over it and there was no jet.
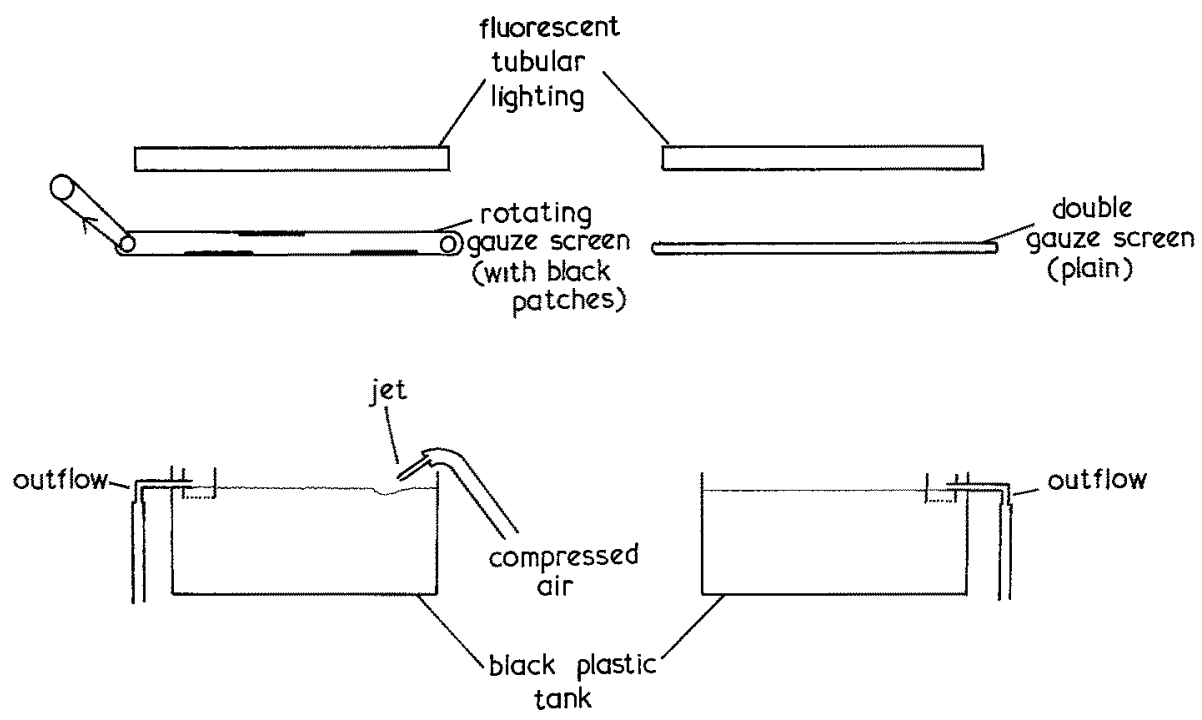

Fig. 3: Diagram of an experiment to test the effect of increasing sensory input for older larvae of the herring Clupea harengus

The most noticeable effect was the more homogeneous distribution of both larvae and food organisms in the experimental tank; this appeared to reduce intra-specific competition and increase the effective volume of the tank. The exigences of other experiments prevented a good comparison of growth and mortality in the two tanks over a long period and, in any event, replicates would have been required. It is considered, however, that techniques of this sort show promise and are worth further investigation.

\section{UNDESIRABLE INPUT IN FISH}

In rearing tanks the most prevalent input is the high physical contact stimulation both from the walls of the tank and from social contacts at high stocking densities. The pattern of allometric growth in tanks is usually abnormal leading to shorter, broader bodies than under natural conditions, for example, in larvae of the 
plaice Pleuronectes platessa (RYLAND 1966) and of the herring Clupea barengus (Blaxter 1969a). So-called bull-headed fish are common in aquaria due either to contact with the walls or high rate of turning

Crowding seems to have a more serious effect. High densities during the young stages usually lead to poorer average growth, even though food is in excess. For instance, this has been shown in goldfish Carassius auratus by WeLTY (1934), in brown trout Salmo trutta by Brown (1946), in white cloud mountain minnows Tanichtbys albonubes and in Barbus tetrazona by Rose (1959), in silversides Menidia by SHAw (1961) and in plaice Pleuronectes platessa, especially following metamorphosis, by Shelbourne (1964) and Bowers (1966b). All authors, and also Blaxter $(1968,1969 \mathrm{~b})$ using herring and pilchard larvae, report a "size-hierarchy" effect, that is a gradual increase in the $\mathrm{r}$ a $\mathrm{nge}$ of size with age in any tank. This is a wellknown phenomenon in rearing experiments.

Many authors also report that tanks of a given volume only seem to allow a limited number of organisms to reach a certain size. The extent to which this phenomenon is socially induced is far from clear. Kalleberg (1958) observed that territory size increased with age in juvenile salmon and trout in a stream tank. This may be due to competition for food. In most experiments, however, food is in excess. Rose's $(1959,1960)$ classic work on developing tadpoles Rana pipiens showed that specific inhibitors were at work, larger individuals producing substances which prevented the growth of smaller individuals. Tests showed that the substances concerned were particulate, were unaffected by many enzymes but were destroyed by methods which were destructive to cellular matter. They might have been sloughed epidermal cells. They did not appear to be accumulated metabolic products because a high density of unrelated species did not have the effect. A similar effect has also been found in fish (see review by Rose 1960) where there is some evidence of population control in tanks of the guppy Lebistes reticulatus, Tanichtbys albonubes, Barbus tetrazona and in trout and ciscoes Leucichthys. Direct experimental work by LAALE \& MCCALLION (1968) has recently shown that the development of the zebra fish Brachydanio rerio could be arrested before gastrulation by the use of the supernatant of homogenates produced from other zebra fish embryos. If such influences prevail under normal rearing conditions, an appropriate rate of water flow needs investigation. MARR (1967) reported a slight effect of turnover of water on the survival of salmon fry, with the least mortality at intermediate flow rates. BLAXTER (1968) found that changing of water produced a highly beneficial effect in the survival of herring larvae in rearing experiments. The extent to which the effect is due to the accumulation of metabolites in the fish species mentioned above can only be examined by experiments designed to test the specif ic nature of the inhibitors. This has not been done. In the case of carp, Cyprinus carpio, poor growth was apparently due to the accumulation of ammonia (КАwАмото 1959).

Other characteristics which are almost certainly socially induced are the incidence of fin biting in young plaice (Riley \& Thacker 1963, Shelbourne 1964, Bowers 1966c), small ones at high density being most susceptible. The extensive amount of pigment deficiency in plaice larvae is described by the same authors. This is again more prevalent at high densities, though the effect of size is not always so 
obvious. For instance, SHELBOURNE (1964) reported that smaller fish were more prone to pigment deficiency, but Riley \& Thacker (1963) found no effect of size. Aggressive behaviour of young salmon, Salmo salar (Symons 1968) in the form of frontal and lateral displaying as well as in charging and nipping was more prevalent during lack of food. Strong hierachies based on size then developed.

Perhaps the most interesting result of all, in the recent experiments on rearing plaice (BOWERS 1966c) was that the larvae reared from parental stock acclimatised in the hatching ponds survived better to metamorphosis $(20 \%)$ than larvae from unacclimatised parents (survival only $4 \%$ ).

The biochemical basis of stress has not been studied in larval fish, although the effect of handling and tank conditions, as well as more artificially induced stress, on the pituitary and adrenal glands of adult fish has received some attention. The buildup of lactic acid in the muscles under conditions of anaerobic metabolism may reach undesirable proportions (PARKer et al. 1959) and hyperactivity can, in fact, be lethal (BLACK 1958). In salmonids confinement, and stress induced by bleeding, were followed by a four-fold increase in corticosteroids and hyperplasia of the adrenal cortex in the sea stage, but there was little effect during the spawning migration (HANE et al. 1966). WEDEMEYER (1969) found a depletion of ascorbic acid in the anterior kidney as a result of stress in salmonids. A different approach, the injection of ACTH, in Tilapia macrocepbala and Fundulus beteroclitus, caused leucopenia (reduction in leucocyte count) at moderate dosages and leucocytosis (increase in leucocyte count) at lower and higher levels (SLICHER \& Pick ford 1962). Immersion in ice water led, in a parallel manner, to initial slight leucocytosis than leucopenia followed after two hours by leucocytosis. This effect still occurred, to some extent, in hypophysectomised animals, indicating that ACTH was not the only factor involved.

\section{DISCUSSION}

A number of points have to be considered when designing rearing tanks in order to achieve adequate input of the appropriate kind. Firstly, the input must be related to the natural environment of the organism. Marine organisms may develop pelagically, in contact with a substrate or buried within it; this will effect not only the light stimuli but also the type of contact, abrasion stimulation and variation in pressure to which the organism is subjected. Secondly, the amount of input required may well increase with age. As the complexity of the nervous system and behavioural responses increase so the input required to maintain them may become greater. Also, there may well be sensitive periods in development where the need for input is especially vital.

On the assumption that the abiotic sensory input in terms of light, other physical and chemical factors, and interfaces is suitable, the biotic input has to be corrected to give optimal social interactions. These interactions must be adjusted to reduce the hierarchy effect, which may well be extremely difficult with high stocking rates in fish farming. Unless cover is provided or the tank equipped with an adequate area of substrate (particularly for settling flat-fish or demersally developing species) excessive territorial behaviour or other social pressures will increase in seriousness with the age and size of the fish. 
Optimum stocking densities may vary. Srlliman \& GuTSELL (1958) investigated this by assessing the rate of "fishing" needed to give a maximum yield from a selfmaintaining breeding population of guppies Lebistes reticulatus. The problem with the rearing tank is that the optimum is always changing. The stringency of rearing requirements must also be appropriate to the subsequent use to which the organisms are put. Animals required eventually for experimentation or "planting-out" must be reared in conditions which will ensure that their behaviour and physiology is as near normal as possible. The battery producer of fish flesh is concerned mainly with the economics of survival and average growth (but always with an ultimate criterion of palatability).

Perhaps the most neglected of all studies is the possibility that marine fish are producing specific inhibitors which might be flushed away by a rapid turnover of water, though a mechanism to retain pelagic food sources must not be overlooked.

Consideration must then be given to the following: (1) How big should the tank be and should the organisms be transferred as they grow, to maintain optimum density? What is the final density required? Can the effective volume of a tank be increased by enlarging the surface area of substrate (eg. by adding galleries)? (2) What is the best colour and material for the walls and floor; should there be a natural substrate? (3) Is the food well distributed to prevent competition? (4) Is intra-specific competition reduced to a minimum by cover? (5) Is the flow rate sufficient to remove specific inhibitors, if they exist? (6) Is there adequate sensory input of light, temperature and other physico-chemical factors?

\section{SUMMARY}

1. Marine organisms reared in tanks, especially larval fish, are almost certainly deprived of sufficient sensory input for the proper development of the sense organs and their associated areas in the central nervous system. Input is also inadequate for the development of learned behavioural and physiological responses.

2. Input of a deleterious kind, as a result of social stress in crowded conditions, may also be present, leading to abnormal behaviour and undesirable morphological consequences. Specific inhibitors may also retard the growth of smaller individuals.

\section{LITERATURE CITED}

BARNETT, S. A., 1964. Social stress. In: Viewpoints in biology. Ed by J. D. Carthy. Butterworth, London, 3, 170-218.

BLACK, E. C., 1958. Hyperactivity as a lethal factor in fish. J. Fish. Res. Bd Can. 15, 573-586.

BLAXTER, J. H. S., 1968. Rearing herring larvae to metamorphosis and beyond. J. mar. biol. Ass. U.K. 48, 17-28.

- 1969a. Feeding and condition of Clyde herring larvae. Rapp. P.-v. Réun. Cons, perm. int. Explor. Mer (in press).

- 1969b. Experimental rearing of pilchard larvae, Sardina pilchardus. J. mar. biol. Ass. U.K. 49, 557-575.

- \& JoNEs, M. P., 1967. The development of the retina and retinomotor responses in the herring. J. mar. biol. Ass. U.K. 47, 677-697. 
- \& Staines, M., 1970. The pure-cone retina and retinomotor responses in teleost larvae. J. mar. biol. Ass. U.K. (in press).

Bowers, A., 1966a. Farming marine fish. Sci. J., Lond. 1966 (June), 46-51.

- 1966b. Growth in hatchery-reared plaice. Rep. Challenger Society 3, (18).

- 1966c. Marine fish culture in Britain. VI. The effect of acclimatisation of adult plaice in pond conditions on the viability of eggs and larvae. J. Cons. perm. int. Explor. Mer. 30, 196-203.

Breder, C. M., JR. \& Halpern, F., 1946. Innate and acquired behavior affecting the aggregation of fishes. Physiol. Zool. 19, 154-190.

BRown, M. E., 1946. The growth of brown trout (Salmo trutta Linn.). J. exp. Biol. 22, $118-129$.

CHow, K. L., 1955. Failure to demonstrate changes in the visual system of monkeys kept in darkness or in colored lights. J. comp. Neurol. 102, 597-606.

Globus, A. \& Scheibel, A. B., 1967. The effect of visual deprivation on central neurons: A Golgi study. Expl Neurol. 19, 331-345.

Grlensten, L., Malmfors, T. \& Norrlin-Grettve, M. L., 1967. Visual and non-visual factors in the centripetal stimulation of post-natal growth of the visual centers in mice. J. comp. Neurol. 131, 549-558.

Hane, S., Robertson, O. H., Wetler, B. C. \& Krupp, M. A., 1966. Adrenocortical response to stress and ACTH in Pacific salmon (Oncorbynchus tshawytscha) and steel-head trout (Salmo gairdnerii) at successive stages in the sexual cycle. Endocrinology 78, 791-800.

Heron, W., 1957. The pathology of boredom. Scient. Am. 196, 52-56.

KalleberG, H., 1958. Observations in a stream tank of territoriality and competition in juvenile salmon and trout (Salmo salar L. and Salmo trutta L.). Rep. Inst. Fresbrwat. Res. Drottningbolm 39, 55-98.

KAWAMOTO, N. Y., 1959. Freshwater fish culture from the physiological point of view. I. Influence of ammonia nitrogen excreted by fishes on their growth in the culture ponds. Rep. Fac. Fish. Univ. Mie-Tsu 3, 104-121.

Laale, H. W. \& McCallion, D. J., 1968. Reversible developmental arrest in the embryo of the Zebra fish Brachydanio rerio. J. exp. Zool. 167, 117-123.

Lindsey, C. C. \& Alr, M. Y., 1965. The effect of alternating temperature on vertebral count in the medaka, Oryzias latipes. Can. J. Zool. 43, 99-104.

MARR, D., 1965. Factors affecting the growth of salmon alevins and their survival and growth during the fry stage. River Bds Ass, $Y b .1965,133-141$.

- 1967. Experiments on the artificial rearing of young Atlantic salmon (Salmo salar L.). In: Council Meeting (C.M.). International Council for the Exploration of the Sea (I.C.E.S.). Sect. Anadromous and Catadromous Fish Committee 1965 (Mimeogr.).

MILLER, R. B. \& MILLER, F., 1962. Diet, glycogen reserves and resistance to fatigue in hatchery rainbow trout. J. Fish. Res. Bd Can. 19, 365-375.

OgNefF, J., 1911. Über die Anderung der Organe der Goldfische nach dreijährigem Verbleiben in Finsternis. Anat. Anz. 40, 81-87.

Parker, R. R., Black, E. C. \& Larkin, P. A., 1959. Fatigue and mortality in troll-caught Pacific salmon (Oncorbynchus). J. Fish. Res. Bd Can. 16, 429.

Pfiugfelder, O., 1952. Weitere volumetrische Untersuchungen über die Wirkung der Augenexstirpation und der Dunkelhaltung auf das Mesencephalon und die Pseudobranchien von Fischen. Wilhelm Roux Arch. EntwMech. Org. 145, 549-560.

QASIM, S. Z., 1959. Laboratory experiments on some factors affecting the survival of marine teleost larvae. J. mar. biol. Ass. India 1, 13-25.

Rasquin, P. \& Rosenbloom, L., 1954. Endocrine imbalance and tissue hyperplasia in teleosts maintained in darkness. Bull. Am. Mus. nat. Hist. 104, 359-426.

Riesen, A. H., 1966. Sensory deprivation. Prog. physiol. Psychol. 1, 117-147.

Rriey, J. D. \& Thacker, G. T., 1963. Marine fish culture in Britain. III. Plaice [Pleuronectes platessa (L.)] rearing in closed circulation at Lowestoft, 1961. J. Cons. perm. int. Explor. Mer 28, 80-90. 
Rose, S. M., 1959. Failure of survival of slowly growing members of a population. Science, N.Y. 129, 1026.

- 1960. A feedback mechanism of growth control in tadpoles. Ecology 41, 188-199.

RrLand, J. S., 1966. Observations on the development of larvae of the plaice Pleuronectes platessa L., in aquaria. J. Cons. perm. int. Explor. Mer 30, 177-195.

SACKETT, G. P., 1965. Effects of sensory deprivation level, visual complexity and age upon light contingent responses during rearing. Anim. Behav. 13, 393-399.

SELYE, H., 1957. Stress of life. Longmans, London.

SHAW, E., 1960. The development of schooling behavior in fishes. Pbysiol. Zool. 33, 79-86.

- 1961. The development of schooling in fishes. II. Pbysiol. Zool. 34, 263-272.

Shelbourne, J. E., 1964. The artificial propagation of marine fish. Adv. mar. Biol. 2, 1-83.

Silliman, R. P. \& Gutseld, J. S., 1958. Experimental exploitation of fish populations. Fishery Bull. Fish Wildl. Serv. U.S. 133, 214-252.

Slicher, A. M., Pickford, G. E. \& Batr, J. N., 1962. Effect of ACTH and cold shock on the white cell count of fishes. Anat. Rec. 142, 327.

SYMons, P. E. K., 1968. Increase in aggression and in strength of the social hierarchy among juvenile Atlantic salmon deprived of food. J. Fish. Res, Bd Can. 25, 2387-2401.

VINCENT, R. E., 1960. Some influence of domestication upon three stocks of brook trout, Salvelinus fontinalis. Trans. Am. Fish. Soc. 89, 35-52.

WEDEMEYER, G., 1969. Stress induced ascorbic acid depletion and cortisol production in two salmonid fishes. Comp. Biochem. Physiol. 29, 1247-1251.

WeLTY, J. C., 1934. Experiments in group behavior of fishes. Physiol. Zool. 7, 85-128.

Wyburn, G. M., PiCKFoRd, R. W. \& HiRsT, R. J., 1964. Human senses and perception. Oliver \& Boyd, Edinburgh, 340 pp.

Author's address: Dr. J. H. S. Blaxter.

Dunstaffnage Marine Research Laboratory

Oban, Argyll, Scotland 